\title{
Restoring Natural Forests as the Most Efficient Way to Water Quality and Abundance: Case Study from Želivka River Basin
}

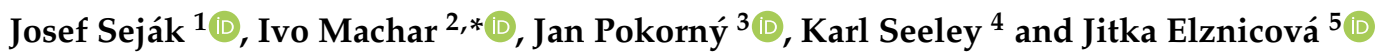 \\ 1 Department of Environment, Faculty of Environment, Jan Evangelista Purkyne University, \\ 40096 Ústí nad Labem, Czech Republic; josef.sejak@ujep.cz \\ 2 Department of Development and Environmental Studies, Faculty of Science, Palacky University Olomouc, \\ 77147 Olomouc, Czech Republic \\ 3 ENKI, o.p.s., Dukelska 145, 37901 Trebon, Czech Republic; pokorny@enki.cz \\ 4 Department of Economics, Hartwick College, Oneonta, NY 13820, USA; seeleyk@hartwick.edu \\ 5 Department of Geoinformatics, Faculty of Environment, Jan Evangelista Purkyne University, \\ 40096 Ústí nad Labem, Czech Republic; jitka.elznicova@ujep.cz \\ * Correspondence: ivo.machar@upol.cz; Tel.: +420-72-450-2474
}

check for

updates

Citation: Seják, J.; Machar, I.;

Pokorný, J.; Seeley, K.; Elznicová, J. Restoring Natural Forests as the Most Efficient Way to Water Quality and Abundance: Case Study from Želivka River Basin. Sustainability 2022, 14, 814. https://doi.org/10.3390/ su14020814

Academic Editor: Alessandra De Marco

Received: 30 November 2021

Accepted: 10 January 2022

Published: 12 January 2022

Publisher's Note: MDPI stays neutral with regard to jurisdictional claims in published maps and institutional affiliations.

Copyright: (c) 2022 by the authors. Licensee MDPI, Basel, Switzerland. This article is an open access article distributed under the terms and conditions of the Creative Commons Attribution (CC BY) license (https:// creativecommons.org/licenses/by/ $4.0 /)$.

\begin{abstract}
This article shows how to restore Central European natural capital effectively. Water in the landscape is primarily sustained by vegetation and soil, most effectively by natural forests and only secondarily by artificial reservoirs. The authors document these facts using a case study from the Želivka River basin (Švihov reservoir), which collects surface water for the metropolitan region of Prague and Central Bohemia. With the Energy-Water-Vegetation Method, the authors demonstrate that the cultural human-changed landscape of the Želivka river basin is able to utilize only about $60 \%$ of its solar energy potential. In $1.5 \%$ of the territory of the Czech Republic, society annually loses supporting ecosystem services at a level higher than 25\% of the annual GDP of the CR 2015. Water retention in the landscape needs to be re-evaluated and addressed in accordance with the thermodynamic principles of life and ecosystem functioning in the biosphere. It is necessary to begin restoring the most efficient natural capital in the landscapes and to return the broad-leaved deciduous forests by intelligent forestation methods to the cultural landscape to the extent justified; this is especially true of the Želivka River basin, which is Czechia's biggest surface drinking-water collecting area.
\end{abstract}

Keywords: drinking water; ecosystem services; Energy-Water-Vegetation Method; natural forests

\section{Introduction}

The first purpose of this paper is to compare the monetary value of four supporting and regulating ecosystem services provided by the current landscape structure of the Želivka river basin (Czech Republic) with that provided by a hypothetical (simulated), fully natural (not influenced by human activities) Želivka watershed land-cover. The map of potential natural vegetation in the Czech Republic [1] was used to simulate the watershed's natural landscape structure without human influence, while the current landscape structure was assessed using CORINE Land Cover 2018 data; the four main ecosystem services were valued in monetary terms using the Energy-Water-Vegetation Method (EWVM) [2]. The EWVM evaluates ecosystems according to their different efficiencies in transforming solar energy into main supporting and regulating ecosystem services.

Our ancestors always treated access to quality drinking water as a foundation of their existence. In the territory of today's Czech Republic (with altitudinal range 115-1602 m a.s.1.), situated in a zone of temperate broad-leaved deciduous forest [3], this was not a major problem up to the beginning of the Industrial Revolution (approx. $1750 \mathrm{CE}$ ). The Czech Republic is sometimes called "the roof of Central Europe," as its watersheds drain to three seas, and this "roof" provided enough good-quality drinking water sources even under 
traditional agricultural cultivation. During the medieval period, traditional agriculture, firmly tied to local land-use and the system of arable and fallow land management, was able to feed up to $30-40$ individuals per $1 \mathrm{~km}^{2}$.

The advent of the Industrial Revolution approximately 250 years ago and the efforts of human individuals and groups to quickly obtain the greatest self-interested benefit began to dramatically change the landscape. Accelerating population growth (from 2.5 to 4.8 million during the 18th century, in the territory of today's ČR) led to a massive conversion of natural forests into agricultural lands, as in many other European countries [4]. The decline in the naturalness of the landscape was also largely driven by industrial forestry, which brought a massive replacement of natural mixed deciduous forests with monoculture stands of spruce with the best yield parameters. This fundamentally disrupted the landscape's ability to retain water. After the Second World War, the collectivization of agricultural land and the political goal of achieving self-sufficiency in cereal production became another factor in the denaturalization and de-watering of the Czech landscapes. These actions made it possible to create "large wide fields" suitable for the application of large-scale mechanization. The communist slogan of achieving self-sufficiency in cereal production, realized by amelioration, drainage, and linear landscape simplification on more than one million hectares of land, led to the creation of dry agrarian steppes, which after the summer harvest convert solar energy into useless heat.

Those calling for continuous economic growth have not had need of a natural landscape for decades. However, after more than half a century of vulgar anthropocentrism in landscape management, the Czech cultural landscape is increasingly showing its unnatural face. Therefore it is important to understand what the natural landscape is. That answer is provided by nature itself (i.e., what man did not do). In its several hundred million years of development, vegetation has been able to optimally adapt to its environment and the different climatic and soil conditions on Earth and has shaped and controlled the environment itself. The form of the natural landscape of the Czech Republic, as it would establish itself without the presence of people in the form of climax vegetation, can be found on the map of potential natural vegetation of the Czech Republic. It is important to note that while the maps of potential vegetation were created by highly able botanists, they are a broad schematic - a human construct for inspiration. Oak or beech deciduous forest etc. does not mean that it is only a deciduous forest. Pollen analyses and historical findings show the presence of conifers (spruce, fir, pine), according to exposure, as well as the nature of the subsoil and the availability of water. For example, in the thousand-year-old sediments of the Vajgar pond in Jindřichův Hradec lying on the Hamerský stream, which springs at an altitude of $750 \mathrm{~m}$ and after $43 \mathrm{~km}$ flows into the river Nežárka at an altitude of $464 \mathrm{~m}$ above sea level, there is a lot of spruce, fir, and pine pollen [5]. Thus, for the reasons of practical landscape restoration management, these time and space vegetation dynamics and heterogeneities must be considered.

Ernst Haeckel, the author of the term "ecology," also defined ecology as the economy of nature, and from a thermodynamic point of view, the economy of nature manifests itself precisely in the increasing efficiency of the use of solar energy in each of the subsequent successive phases towards climax. The world-renowned ecologist E. Odum was the first to link the flow of solar energy with succession [6]. He showed that succession is a directed, and thus a predictable, self-organized process of replacing one species with another, culminating in a stabilized climax ecosystem where maximum biomass and symbiotic functions between organisms are generated per unit of solar energy [7]. The climax ecosystem, which in the Czech Republic takes the form of mixed forests dominated by deep-rooted deciduous beech and oak tree species, can convert up to $2 / 3$ of the incoming solar energy by evapotranspiration into latent heat, which provides cooling on summer days, reduces daily temperature amplitude, and equalizes temperature differences. Moreover, it is precisely the mitigation of temperature extremes, together with the maintenance of water in the landscape, which form two basic life-giving and life-supporting ecosystem functions maximized by mixed climax vegetation with the dominance of deep-rooted deciduous tree 
species. J. Lovelock clearly emphasized this in his book, writing that "the Earth's natural ecosystems regulate the climate and chemistry of the Earth and are not there merely to supply us with food and raw materials" [8]. Further, these ecosystem functions of natural vegetation that help to control Earth's climate are so powerful that humans are far from being able to replace them with their technological capabilities.

If, in the territory of the Czech Republic, about $1000-1100 \mathrm{kWh} / \mathrm{m}^{2}$ of solar energy is produced on average per year, and natural vegetation (deciduous deep-rooted forests with plenty of water; wetland ecosystems) is able to efficiently use and convert about $2 / 3$ of this energy through evapotranspiration and latent heat, creating and controlling basic living conditions (air-conditioning, water retention, oxygen production, soil-forming, environment for biodiversity), then the loss of every one square meter of natural vegetation in favor of built-up or otherwise paved surfaces means a permanent annual loss of approx. $660-700 \mathrm{kWh} / \mathrm{m}^{2}$. At a price of approximately $€ 0.12 / \mathrm{kWh}(1$ Euro $=$ CZK 25), this means an annual loss of at least $€ 80 / \mathrm{m}^{2}$, or an annual loss of solar energy of approximately $€ 0.8$ million/ha/year due to liquidated natural vegetation [2,9]. Similarly, all living species on Earth suffer together on all inhabited continents from these mostly man-made thermodynamic losses, which attenuate climatic control power by decreasing natural vegetation.

Increasing climatic extremes provide a warning that the continental landscape is not primarily important for the short-term economic benefit (profit) of human beings and their groups, but for its unique life-supporting ecosystems, because for hundreds of millions of years they have been producing essential ecosystem functions and services without which the human species could neither have emerged, nor exist in the future. These are the supporting and regulating functions and services of natural ecosystems that are used free of charge by humans as gifts of nature and as free public goods (air-conditioning functions such as mitigating temperature extremes, clean air to breathe with sufficient oxygen, clean water resources and water in the landscape, an ozone layer protecting everything living on Earth's continents, fertile soil as a product of natural forests, etc.). Moreover, these free ecosystem functions and services are increasingly lacking on a global scale under the influence of the expanding economic sector.

In this paper, we will show this by an example of irreplaceable energy losses from the cultural landscape of the Želivka River basin, where surface water accumulates for the Prague and Central Bohemian agglomerations.

\section{Materials and Methods}

\subsection{Case Study Area Description}

The Želivka river basin $\left(1188 \mathrm{~km}^{2}\right)$ is located about $70 \mathrm{~km}$ southeast of Prague $\left(49^{\circ} 18.4^{\prime}\right.$ $49^{\circ} 44.5^{\prime} \mathrm{N}, 14^{\circ} 49.49^{\prime}-15^{\circ} 27.4^{\prime} \mathrm{E}$ ) and occupies about $1.5 \%$ of the total area of the Czech Republic (78 $\left.869 \mathrm{~km}^{2}\right)$. This paper presents the results of assessing the loss of four lifesupporting and regulating ecosystem services caused by degrading anthropogenic land-use changes from natural land-cover (known as potential natural vegetation) on the territory of the Želivka river basin.

Potential natural vegetation (PNV) is the hypothetical vegetation cover in equilibrium with climate and habitat conditions (exposure, geology, soil, slope) that would exist at a given location if it were not impacted by human activities [10,11]. PNV is useful for raising public awareness about land degradation and for estimating land potential. From the viewpoint of solar energy inflow and the rate of efficiency of its use, it is important that ecosystem communities develop in self-organized succession stages, increasing the efficiency rate and culminating in stabilized mature climax vegetation with the highest rate of efficiency of solar energy use in producing basic life-supporting conditions for sustaining life [7].

If the landscape of the Želivka watershed (altitudes 380-700 m a.s.l.) were not influenced by humans, successive self-organization would develop climax vegetation of oak and beech forests, as shown in Figure 1. 


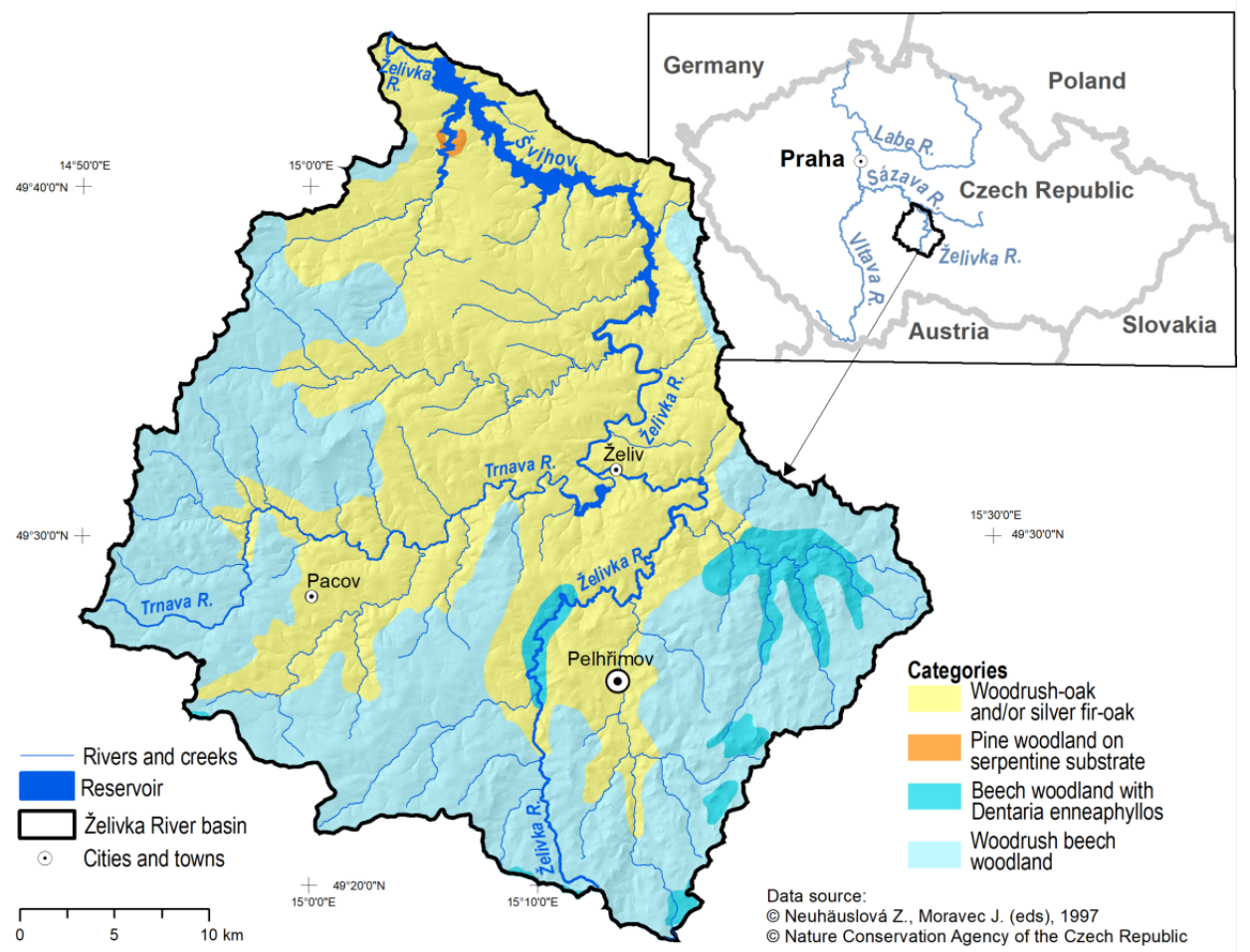

Figure 1. Potential natural vegetation in Želivka River basin.

In 1965 it was decided to use the Želivka river as the main source of surface drinking water for the growing Prague and central Bohemian agglomeration, as the river basin is in a relatively less inhabited area of the Bohemian-Moravian Highlands (75 inhabitants $/ \mathrm{km}^{2}$ compared to national average of 136), although it has been relatively intensively used for agricultural production. The Švihov surface water reservoir (with $266 \times 10^{6} \mathrm{~m}^{3}$ capacity) is situated in an agriculturally intensively managed landscape; the share of agriculturally used areas in the catchments of individual tributaries is in the range of 50-80\%. Crops with combined use are grown here in large areas (partly as a source of substrate for biogas plants), mainly broad-leaved crops, especially maize, rape, and potatoes. Plant protection chemical products are widely used here. Currently, the area is anthropogenically loaded with human settlements and partly with industrial production [12]. An integral part of the Švihov reservoir catchment area is the upstream settling reservoirs: Němčice on the Sedlický brook, Trnávka on the Trnava watercourse, and the Sedlice and Vřesník reservoirs on the Želivka watercourse.

Vegetation is a dynamic feature; therefore it is important to reference potential natural vegetation to the time period of interest. Our interest is to compare the current Želivka river basin land cover with the hypothetical highest potential vegetation state assuming natural (undisturbed) physical conditions. Knowing the losses of solar energy caused by current land-cover, we can propose the future man-managed sustainable landscape restorations that will optimize the competing goals of necessary economic activities in the land-use of the Želivka watershed with sustainability interests in optimally restoring the watershed ecosystem's thermodynamic and biophysical potential.

The next map (Figure 2) presents the current structure of the river basin landscape. Based on the CORINE Land Cover from 2018, Figure 2 shows how long-term utilization by people has changed and greatly fragmented the landscape of the Želivka River basin. The conversion of deciduous forests into agricultural land, dwellings, and, in the case of forests for the last two centuries, dominant spruce forests has brought a significant decrease in the quantity and quality of ecosystem services in this river basin. 


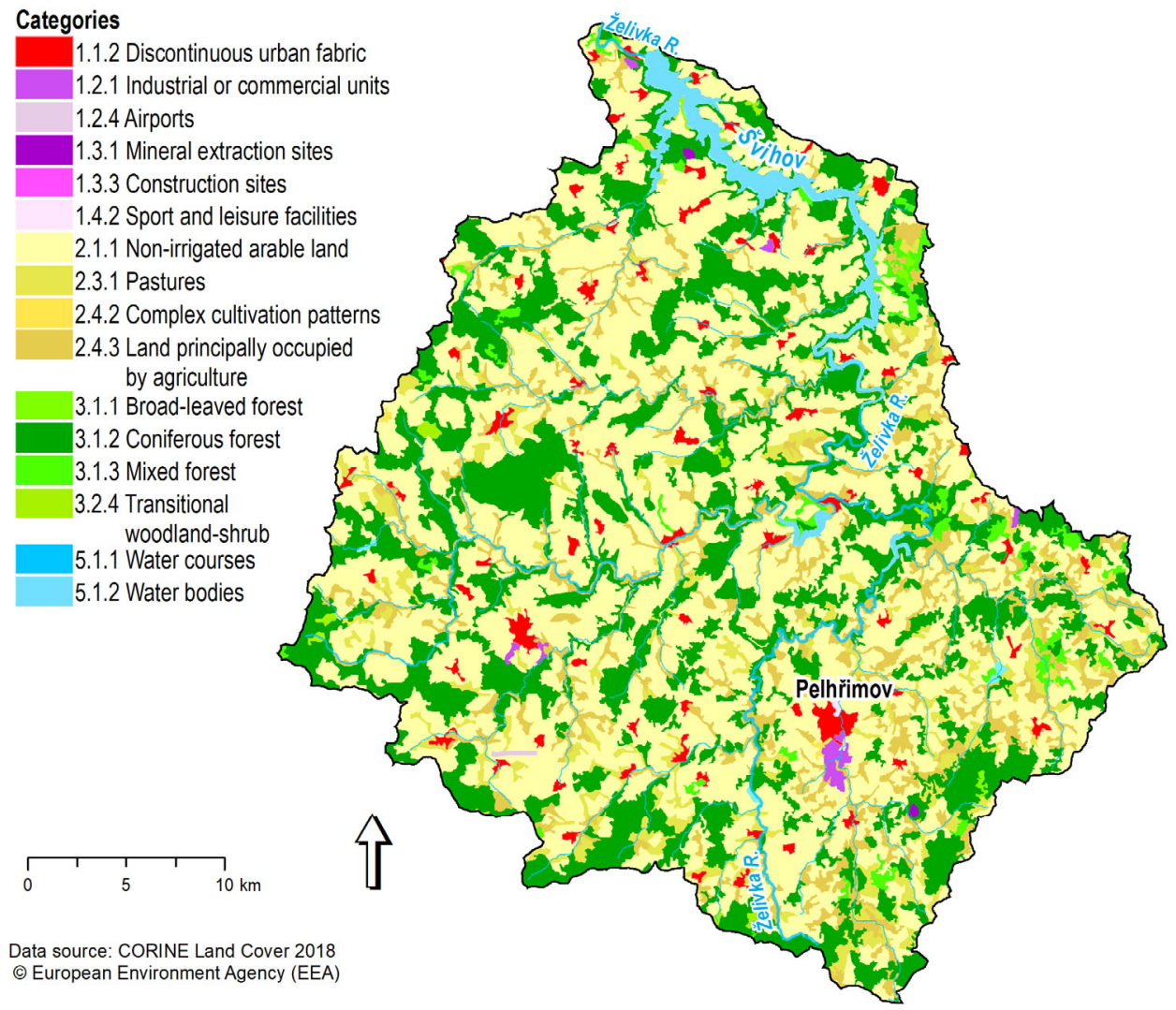

Figure 2. Landscape structure based on Corine Land Cover 2018 in the Želivka River basin.

\subsection{Energy-Water-Vegetation Method for Valuing Freely Delivered Supporting/Regulating Ecosystem Services}

Traditionally, the only ecosystem provisioning services that are economically appreciated and valued by humans and markets are those that provide direct economic benefits to human individuals and groups (direct use values such as food, timber, and other material goods, and built-up areas, industrial zones, housing, technical, and transport infrastructure). Since ecosystem-supporting and regulating services have been provided free of charge to people since their origins (climatizing services, soil formation, air and oxygen for breathing, water for drinking, ozone protective layer, etc.), it is clear that, up to now, most human beings have weak personal preferences for such self-evident and free services and often do not know anything about them.

If economic assessment of non-market ecosystem services is carried out in market economies using standard valuation methods of mainstream utilitarian welfare economics in the form of identifying the hypothetical willingness of individuals to pay for them (e.g., through a contingent valuation questionnaire or derivation from related markets, hedonic methods, etc.), the results of such unilateral demand-side assessments of individual ecosystem services (e.g., by means of contingent assessment questionnaires) systematically underestimate their true life-supporting significance. This can be seen directly in the famous article by R. Costanza's team from 1997 [13]. In this review paper, a team of environmental experts presented for the first-time global estimates of the annual values of ecosystem services from the world's core biomes. The total annual value of the seventeen services of the sixteen biomes in the world was estimated to be approximately 1.8 times the then annual world gross domestic product (GDP). The authors proceeded from the results of approximately a hundred valuation studies, mainly based on the determination of individuals' willingness to pay for these ecosystem services (ES).

In updating the review paper of Costanza et al., by quantifying ES values using standard subjective methods of individuals' willingness to pay for such services from 
several hundred valuation studies, scientists have arrived at perverse value relations, according to which the temperate forest is the least valuable terrestrial ecosystem (temperate forest $\$ 3137 /$ ha/year, meadow $\$ 4166 /$ ha/year, cropland $\$ 5567 /$ ha/year, urban land $\$ 6661 /$ ha/year), despite the fact that forests are the main representative of climax vegetation on the continents, most effectively using incoming solar energy for vital supporting and regulating ecosystem services [14]. Therefore, to continue deciding on landscape changes according to these counterproductive unilaterally utilitarian values would mean totally destroying it, i.e., destroying life on earth. This is also the reason why Costanza et al. recently recommended an integrated approach to the valuation of natural capital and ecosystem services as their contributions toward the goal of the sustainable wellbeing of the whole system of humans and the rest of nature [15].

In any case, there is an urgent need, related to A. Marshall's heritage, to define economic value as an equating result of comparing human benefits from the use of nature with the costs necessary for their creation [16]. More specifically, there is a need to start evaluating ecosystems and their ecosystem services by comparing the above-mentioned human benefits with the costs that nature and humans incur through anthropogenic changes of natural landscape in the form of solar energy potential losses. According to the above thermodynamic criterion of solar energy efficiency use, implemented in the Czech Republic using the Energy-Water-Vegetation Method [2], it is a natural multi-storey deciduous mixed forest, which, in the temperate climate zone, provides maximum supporting ES; these supporting ES in turn form the basis for all other ES (temperate forest $€ 1-1.4$ million/ha/year, grasslands $€ 0.6-0.8$ million/ha/year, agricultural land $€ 0.5-0.8$ million/ha/year, urban land $€ 0.2-0.6$ million/ha/year).

For example, the development of 1 ha of floodplain forest will bring an economic rent from the "land development" of about $€ 5$ thousand/ha/year, but it will cause a loss of approx. $€ 1$ million/ha/year (i.e., 200 times more) of the technologically irreplaceable biophysical thermodynamic supporting and regulating ES of the removed floodplain forest!

The quantification of the enormous losses of solar energy and consequently the losses of supporting and regulating ES under the influence of the destruction of natural vegetation is in this article illustrated by the cultural landscape of the Želivka River Basin.

If we want to express the real economic value of ecosystem-supporting and regulating services, we must express the socio-ecological costs of dissipated energy losses associated with anthropogenic landscape changes. Over the last century, humans have transformed and destroyed half of the world's most valuable natural ecosystems, and experts are ever more urgently warning that with the increasing scarcity of natural ecosystems, irreversible changes may occur in the maintenance of basic life-supporting conditions (climate, air structure, biodiversity, etc.). It is best to express the increasing scarcity of natural ecosystems by calculating the costs we must incur to replace their individual services.

\subsection{What Can Natural Vegetation Do with Solar Energy}

The Energy-Water-Vegetation Method (EWVM) developed by an interdisciplinary team in 2007-2009, based on the quantification of monetary values of ecosystem services from the symbiosis of solar energy, water, and vegetation, shows increasing ecosystem function losses resulting from most anthropogenic landscape transformations [2].

In accordance with the thermodynamic nature of life, ecosystems can be understood as non-equilibrium dissipation processes [7]. The EWVM is based on trans-disciplinary evidence that successively later ecosystems are more efficient than previous vegetation in terms of solar energy use. The EWVM is supported by W. Ripl's Energy-Transport-Reaction model $[17,18]$ and estimates the main benefits that natural ecosystems provide in terms of the indirect use values of the four supporting and regulating functions and services to society, promoting a small water cycle (mitigating temperature extremes, landscape watering service, oxygen production service, and biodiversity service).

Under the influence of incoming solar energy, the vegetation species are self-organized by successive processes, gradually moving towards the climax species of natural deciduous 
forests, which retain higher humidity and lower temperature extremes compared to the surrounding landscape, as shown by Reichholf [19], and represent the highest degree of ordering the ability of the natural vegetation to do the work by means of massive water transformations and photosynthesis.

As a result of the anthropogenic transformation of natural forests into semi-natural agricultural lands, the entropy of the landscape is increasing (i.e., the degree of landscape ordering is decreasing) and it grows still further with completely "de-naturalized" buildings, the creation of impermeable surfaces, and the drainage of water from the landscape. This can be illustrated by the resulting table of specific values of four selected ecosystem services for 24 groups of habitats in the Czech Republic-see Appendix A.

Conceptually, the EWVM method is based on the observation that the thermodynamic performance of an ecosystem is determined by the ratio in which the incoming solar energy flow is converted into latent or sensitive heat in different ecosystems.

Ecosystems of natural forests and wetlands with plenty of water are able to efficiently use most of the incoming solar energy by converting it to latent heat by means of evapotranspiration, thereby cooling and subsequently warming the local environment in a cold environment. If we calculate each of the ecosystem functions separately using the cost of compensation and then add the resulting values (as utilitarian procedures do), we get natural ecosystems with annual benefits of $€ 50-140 / \mathrm{m}^{2}$. To avoid even attempting such calculations, proponents of utilitarian evaluation have excluded the internal ecosystem function (or supporting services) from the surveillance framework as an alleged duplication with other services, in the recent international classification of ecosystem services CICES [20].

The ecosystem-supporting functions of nature, the most valuable thing that natural ecosystems create for humanity and for other heterotrophic living species, remain outside the framework of economic systems. As can be seen from Table A1 in the Appendix A, in the Czech Republic the four quantified services annually create a flow of benefits for society (evaluated by the cost of their technological replacement) amounting to over $€ 5700$ billion, which represents about thirty times the annual gross domestic product of the Czech Republic in 2019 ( $€ 187$ billion in purchasing power parity).

\section{Case-Study Results}

The Želivka River Basin is the main collection area for surface water for drinking purposes for the Prague and Central Bohemian agglomerations. Using the map of potential natural vegetation in the Czech Republic, and using the systematic evaluation methodology of four basic ecosystem services in the Czech Republic [2,21], we can estimate the anthropogenic long-term losses of services of the ecosystems in the Želivka watershed with Švihov reservoir, delivering surface water for about 1.5 million inhabitants of the Czech Republic.

It is clear from the map that two main species of mixed deciduous, deeply rooted forest would dominate in the catchment area: flowering beech forests (approx. 50\% of the catchment area) in the higher peripheral parts of the catchment area and flowering oak forests in lower areas. The Želivka basin is mostly a highland area where there is a natural mixed forest with conifers, which provide cooling in springtime. The upper parts of the watershed's rivers are at altitudes of around 500-700 m (submontane belt) and, depending on the exposure and slopes, the conditions for mixed forests composed of beech, spruce, fir, and other deciduous and pine trees exist.

In summary, mixed forests with dominance of deep-rooted deciduous tree species would significantly improve water retention and water quality in the river basin and create conditions for rapid restoration of wetland areas. They would provide ideal ecosystem services for climate and soil-formation (in the form of a balance of production and destruction of biomass), as well as water retention and health services. 
Four ecosystem services in the Želivka water basin with potential natural vegetation cover would achieve approximately $€ 123.5$ billion (Table 1 ) each year, i.e., more than two thirds of the annual GDP of the Czech Republic in 2015 ( $€ 179$ billion).

Table 1. Four ecosystem service values in Želivka River basin with potential natural vegetation.

\begin{tabular}{cccc}
\hline $\begin{array}{c}\text { Type of Potential Natural } \\
\text { Vegetation }\end{array}$ & $\begin{array}{c}\text { Area } \\
\text { (Hectares) }\end{array}$ & $\begin{array}{c}\text { 4ES } \mathbf{1}^{\mathbf{1}} \text { Value } \\
\left(\boldsymbol{\epsilon} / \mathbf{m}^{\mathbf{2}} / \text { year) }\right.\end{array}$ & $\begin{array}{c}\text { Total Annual } \\
\text { 4ES } \mathbf{1}^{\mathbf{1}} \text { Value } \\
\left(\boldsymbol{€} \text { B1ns }=\mathbf{1 0}^{\mathbf{9}}\right)\end{array}$ \\
\hline $\begin{array}{c}\text { Woodrush-oak and silver } \\
\text { fir-oak forests }\end{array}$ & 59.78 & 104 & 61.65 \\
$\begin{array}{c}\text { Pine woodland on serpentine } \\
\text { substrate }\end{array}$ & 153 & 65 & 0.1 \\
$\begin{array}{c}\text { Beech woodland } \\
\text { Woodrush beech woodland } \\
\text { In total }\end{array}$ & 5068 & 104 & 5.27 \\
\hline
\end{tabular}

${ }^{1} \mathrm{ES}$ = Ecosystem services; 4ES = four supporting and regulating ES (climatizing double service of cooling by latent heat and warming by condensation; short water cycle i.e., retaining water in ecosystem; oxygen production; habitat provision service for biodiversity). For more methodological details see [2] and the 4ES values for the Czech Republic in Appendix A.

During the four decades of the centrally planned economic system (1948-1989), with agricultural cooperatives and state enterprises in the Czech Republic in general and in the Želivka watershed specifically, there was a politically enforced extractive goal of achieving self-sufficiency in grain production, as well as massive drainage of agricultural fields. This significantly reduced the landscape's capacity to deliver invisible but critically important life-supporting ecosystem services (Table 2).

Table 2. Four ES values in Želivka River basin based on 2018 CLC categories.

\begin{tabular}{|c|c|c|c|c|}
\hline $\begin{array}{l}\text { CLC }^{1} \\
\text { Code }\end{array}$ & Land Cover 2018 by CLC $^{1}$ & $\begin{array}{c}\text { Area } \\
\text { (Hectares) }\end{array}$ & $\begin{array}{l}\text { 4ES }{ }^{2} \text { Value } \\
\left(€ / \mathrm{m}^{2} / \text { Year }\right)\end{array}$ & $\begin{array}{c}\text { Total Annual } \\
4 \mathrm{ES}^{2} \text { Value } \\
\left(€ \mathrm{Blns}=10^{9}\right)\end{array}$ \\
\hline 112 & Discontinuous urban fabric & 2992 & 49 & 1.466 \\
\hline 121 & Industrial commercial units & 387 & 23 & 0.089 \\
\hline 124 & Airports & 52 & 54 & 0.028 \\
\hline 131 & Mineral excavation sites & 51 & 31 & 0.016 \\
\hline 133 & Construction sites & 0 & 34 & 0.000 \\
\hline 142 & Sport and leisure facilities & 36 & 40 & 0.014 \\
\hline 211 & Arable land & 59,632 & 52 & 31.009 \\
\hline 231 & Pastures and meadows & 6428 & 55 & 3.535 \\
\hline 242 & Complex cultivation & 61 & 51 & 0.031 \\
\hline 243 & $\begin{array}{l}\text { Agriculture natural } \\
\text { vegetation }\end{array}$ & 12,011 & 64 & 7.687 \\
\hline 311 & Broad-leaved forests & 92 & 93 & 0.086 \\
\hline 312 & Coniferous forests & 33,195 & 84 & 27.884 \\
\hline 313 & Mixed forests & 1913 & 94 & 1.798 \\
\hline 324 & Woodland shrub & 416 & 66 & 0.275 \\
\hline 511 & Water courses & 63 & 75 & 0.047 \\
\hline 512 & Water bodies & 1509 & 75 & 1.132 \\
\hline- & Total & 118,838 & - & 75.097 \\
\hline
\end{tabular}

${ }^{1} \mathrm{CLC}=$ Corine Land Cover, ${ }^{2}$ 4ES = four supporting and regulating ES (see Table 1 ).

In the studied river basin, four supporting and regulating ecosystem services are only producing around $60 \%$ of the value of their natural potential.

If agroecosystems cover $2 / 3$ of the catchment area, and the profitability of agricultural production is currently fully secured by subsidies from the public budgets of the Czech Republic and the EU, it is clear that the depleted and aged agricultural land in the catchment may be more appropriately used for afforestation in the upper parts of the river basin, the application of catch cropping management in agricultural fields (crops grown in the 
space between two main crops or at a time when no main crops are being grown), and the construction of wetland ponds for catching eroded nutrients, thus transforming the role of farmers through environmental subsidies aimed at restoring the most effective natural capital to ecological landscape managers who care for its life-giving ecosystem functions and services.

By such complex adaptive landscape management in the Želivka River basin, the functioning of its ecosystems can be revitalized most effectively, so that the trend of their decline is turned around and the levels of ecosystem functions and services begin to approach their natural potential.

\section{Water Quality Development in Želivka River and Tributaries}

In the mid-1960s the Želivka river basin, as a less inhabited area of the BohemianMoravian Highlands, was consciously selected to be the main source of surface water for an ever more densely populated Prague and the central Bohemian agglomerations. However, such a decision also had a negative connotation in the fact that this had been an area with relatively intensive industrial agricultural production, as the share of agriculturally used areas in the catchments of individual tributaries had been in the range of 50-80\%. Compared to the average for the Czech Republic, the Želivka river basin shows a lower forest percentage ( $30.5 \%$, vs. average in $C R=33.7 \%)$ and a higher arable land percentage (46\%, vs. CR $38.1 \%)$. In the catchment, 5247 of farmer plots are registered, with an average area of 9.77 ha of arable land per plot. In the catchment, there are 171 plots / fields with an area above 40 ha. More than $65 \%$ of arable land is on slopes over $5 \%$, i.e., endangered by erosion [12].

Due to the higher share of arable lands and large-scale industrial agriculture, based on the use of chemical fertilizers and pesticides, the quality of the water in the Želivka river is distinctly threatened in tributaries that are endangered by erosion and the infiltration of nitrates, pesticides, and phosphorus, as well as by eutrophication, besides other specific pollution compounds, e.g., drugs, hormonal substances, personal care products, anticorrosive substances, Bisphenol A (BPA), and others from waste water point sources.

The problem of eutrophication in surface water reservoirs increased especially during the warm and dry five-year period 2014-2018, when Cyanobacteria (blue-green algae or microalgae) occurred excessively in a so-called water bloom, in water reservoirs that are used, e.g., as a source of drinking water, represented a serious ecological problem. The main nutrients contributing to eutrophication are phosphorus and nitrogen.

At the Švihov water reservoir, the concentration of total phosphorus has not exceeded $0.05 \mathrm{mg} / \mathrm{L}$, and since 2013 it has stayed at approximately $0.02 \mathrm{mg} / \mathrm{L}(20 \mu \mathrm{g} / \mathrm{L})$. The concentration of total phosphorus is moderated (reduced) by permanent abatement activities aimed at point sources and by the removal of sediments from smaller water reservoirs at tributaries. In the 1970s, concentrations of nitrate at Švihov reservoir fluctuated between 10 and $50 \mathrm{mg} / \mathrm{L}$; they increased from the 1980s through the first decade of the 3rd millennium, and after 2010 the maxima have dropped to $40 \mathrm{mg} / \mathrm{L}$. Nitrate concentration at the dam is relatively stable (low fluctuation), with a maximum of $30 \mathrm{mg} / \mathrm{L}$; since 2010 the maximum has decreased to $20 \mathrm{mg} / \mathrm{L}$ [22].

In spite of continuing abatement activities, in 2018 the problem of water blooming even in Želivka river tributaries was at a critical level. Together with negative modelling forecasts for further climate warming (though that remains to be substantiated) and with increasing levels of specific pollution compounds, both factors have contributed to implementing a new investment in a new filtration stage filled with granular activated carbon, which is being implemented (investment cost of $€ 48$ million) below Švihov dam and is unique in many ways not only in the Czech Republic, but in the whole of Central Europe.

\section{Discussion}

Since the 1970s, the New York City water supply system in its Catskill Mountain region has been an excellent example of how to cheaply forego building a filtration plant 
by protecting the ecosystem services of its watershed [23]. However, in a comparison with conditions in the Želivka watershed, large differences cannot be overlooked. In the second decade of the 21st century, the Czech Republic was hit by a several-year period of dry weather, with a shortage of precipitation. The warm and dry five-year period 20142018 has led to a high danger that the main source of drinking water for the Prague and Central Bohemian agglomerations will fail, being burdened by extreme water blooming. In such a difficult situation there was no time for bargaining with individual polluters in agriculture and industry to resolve their environmental conflicts (as was done in the Catskill Mountain region), and the construction of second-step filtering station was a necessary technological solution in order to assure a safe surface-water delivery system. Moreover, while in the Catskill Mountain region around $90 \%$ of the watershed is covered by natural forests, in the Želivka watershed the agroecosystems and anthropogenized productive spruce forests dominate.

In restoring the natural forests in the Želivka river basin, we recommend the utilization of the internationally verified Miyawaki forestation method [24], which offers the most efficient and quickest way to cool the air and generate oxygen, to clean waters and regulate precipitation and wind, to restore terrestrial biodiversity, and to reduce fertilizer runoff into rivers that causes algae blooms.

In the future preservation of the Želivka watershed, the best-practice experience from the New York City watershed in the Catskill Mountain region remains fully valid and recommendable, as it is an example of how to reconcile different economic and environmental interests of principle stakeholders and achieve the cheapest win-win effects in both the farm and municipalities sectors, with polluters on one side and drinking water consumers and their city administrators and political representatives on the other side. Afforestation of the most sensitive areas remains one of the most important measures that should be pursued politically by surface water consumers and their representatives [25].

In the current world of growing climatic extremes, access to quality water is becoming a priority goal in most countries. This priority has been underlined at all world sustainability summits starting in 1992 in Rio de Janeiro up to the last meeting in Rio+20 in 2012. Many authors explain the losses of water in the landscape as a result of global climate changes and climate warming, but in most cases that is not the primary cause of such losses. The primary drivers should be sought in anthropogenic transformations and fragmentations of the natural landscape. The drained landscape overheats and the rising warm air sucks moisture from the surroundings and carries the moisture high into the atmosphere, and the water does not return in the form of small and frequent rainfall; in this way, the water circulation is disrupted.

It is not only economic agents and greedy individuals who are willing to exchange environmental quality for personal profit and who contribute to such negative anthropogenic influences on the remaining fragments of natural landscape, but also some scientists, who rely on simplified global climate modelling. One such example is an article by Bala et al., in which the authors found that the global-scale deforestation outside the tropics has a net cooling influence on Earth's climate [26]. Such a modelling conclusion is in direct contradiction with the real functioning of the biosphere and of ecosystems, and with the personal experience of many perceptive individuals, who understand how forest ecosystems behave. If there are any specific characteristics of the forest ecosystem, it is the fact that it has the ability to mitigate the local, regional and continental climate extremes (fluctuation of temperatures in the forest is lower than in open landscape) and it also has the ability to retain water inside the ecosystem (atmospheric moisture is higher than in open landscape). Although the authors warn that deforestation outside the tropics "should not necessarily be viewed as a strategy for mitigating climate change, because, apart from their climatic role, forests are valuable in many aspects", by reducing the climatic role of forests to albedo only, and by omitting their active mitigating role in control of climate, the authors' conclusion damages the protection of natural vegetation. 
Although many scientists agree that supporting and regulating ecosystem services are irreplaceable preconditions of the human species' evolution and existence, many of them refuse to incorporate these services into human decision-making in landscape management. Herman Daly recently called such an omission of solar energy flow from our theory of production and from the national income accounting a monumental error [27]. The sun is the primary source of energy for Earth's climate system. By managing the landscape and changing the natural land cover, humans influence the distribution of solar energy and the latent heat/sensible heat ratio, as explained by Bowen in 1926 [28].

Valuators of ecosystem services by the standard concept of WTP reiterate that their estimates are very likely to significantly underestimate the true importance of nature and its biomes, because the services assessed are very incomplete, and because respondents have a very limited knowledge of the phenomena being evaluated in the questionnaires to determine willingness to pay. However, the main problem is not an overall underestimation, but the fact that unilateral utilitarian valuations set up a crooked mirror of the wrong value relations for the restoration of the most valuable natural assets in market economies. It is clear that such utilitarian-derived relations are very biased in relation to the actual effectiveness of individual groups of ecosystems and, if not supplemented by solar energy costs from the cultural landscape, directly impede the effective restoration of natural capital in the form of natural forest vegetation species and their supporting, regulating, and cultural services.

The separation of the results of one-sided utilitarian methods of ecosystem services evaluation from their thermodynamic and biophysical bases is even more evident from the comparison of absolute quantities. If ecosystem services of forests are estimated by preferential methods at $\$ 3137 /$ ha/year, then their ecosystem functional benefit for maintaining basic life-supporting conditions represents an amount more than three hundred times higher, approximately $\$ 1$ million/ha/year. This implies that most people still greatly underestimate the real importance of natural ecosystems in maintaining basic living conditions.

Standard economists are reluctant to use the replacement cost method for evaluating ecosystem services because they believe it is not an economic value (or, in their conception, a value as an individual's marginal benefit), but a cost. However, if the actual economic value is always the result of an equating comparison of the costs and benefits of a given good or service, and if the social costs of the loss of ecosystem functions significantly dominate, then they must be compared with the results of non-market ecosystem valuation demand methods. The need for the perception of economic value as a result of constant cost-benefit comparison was aptly illustrated by perhaps the greatest of the neoclassical economists, A. Marshall, comparing it ironically to shearing scissors: "We might as reasonably dispute whether it is the upper or the under blade of a pair of scissors that cuts a piece of paper, as whether value is governed by utility or cost of production" [16].

A technique that partly competes with our EWVM is the open-access software, already frequently used, of the Soil Water Assessment Tool (SWAT). The SWAT model is a deterministic, continuous, watershed-scale simulation model developed by the USDA Agricultural Research Service [29]. The model was developed to assist water resource managers in assessing the off-site impacts of climate on the water balance in watersheds and larger river basins [30,31].

An important gap in SWAT is the lack of attention given to the active role of vegetation and crop processes. None of the SWAT-applying papers reported any adaptation to the crop parameters, or any crop related output such as leaf area index, biomass, or crop yields. A proper simulation of the land cover is important for obtaining correct runoff generation, evapotranspiration, and erosion computations, as shown by van Griensven et al. [32].

But even if in direct forest restoration we try to avoid long-term succession processes by the direct application of climax forest strata, we must decide carefully, as specific climatic factors and soil conditions must be respected, as well as specific disturbance regimes.

The restoration of natural forests with complex layers of various natural trees is the basis for the restoration of natural capital in the Želivka river basin; it is the safe way 
to ensure a sufficient inflow of water with a low nutrient content into the accumulating wetlands and ponds and further into the Švihov reservoir. The issue will be how to restore and manage forests intelligently, in the fields, and how to treat water from wastewater treatment plants, so that we retain water for its transpiration and nutrients in a humanpopulated landscape. In the Želivka river basin, it is a matter of restoring climatically functional forests, while in agricultural fields it is about agricultural management technics and capturing eroded nutrients necessarily flowing from fields into newly constructed wetlands and especially also ponds, thus keeping waters in Švihov reservoir as clean as possible.

To this day, and especially in the last two centuries, people have been making totally counterproductive uses of nature. They displace and remove natural vegetation and water from the land and, in accordance with the prevailing anthropocentric concept of economic value, perversely place the least value on the ecologically most valuable parts of the landscape, ascribing higher values to urban lands. This removes energetically powerful free-of-charge services that mitigate temperature extremes and enable the maintenance of water and nutrients in ecosystems, leading to long-term desertification, increased climate extremes, environmental erosion, and loss of ecosystem services.

Healthy ecosystems (with plenty of water and vegetation) can use up to about $60-70 \%$ of the incident solar radiation in their free-of-charge air conditioning and retention services (water and nutrient retention), two to three orders of magnitude higher than people's technological capability to replace these services of natural vegetation.

The transition to sustainable land use includes understanding the high social cost and counterproductive quality of the short-term use of nature for our own benefit, respecting the nutritional needs of society, using ecological valuation methods, and starting to return natural vegetation wherever possible. The obligation to return natural vegetation and water to the surface layers of the land must be reflected in all projects linked to the imposition of environmental damage. In this sense, the Czech Republic's Act on the Prevention of Environmental Damage and the EU Environmental Liability Directive need to be amended so that they apply not only to selected parts of specially protected areas, but to the whole territory of the Czech Republic and other EU member countries.

The most effective way to restore the sustainability of agricultural land and aging agricultural soils is to restore natural mixed beech and oak forests and to create pond-type wetland ecosystems at morphologically appropriate locations that can fulfil a variety of production and ecological functions and services [33]. In this sense, the Czech concept of the Territorial System of Ecological Stability [34] is an excellent start, but at the same time only an insufficient skeleton, which lacks the living muscle for firm connection and real landscape performance of the extended natural vegetation in the form of life-giving ecosystem functions and services [35].

These basic findings and recommendations on the need for an integrated economic and ecological valuation of the Czech and European landscape meet the objectives of the 7th and the draft of 8th EU Environment Action Programs [36,37], in which natural capital recovery has been set as one of the most important Union objectives and environmental measures in the landscape are given a higher preference than in previous programs.

\section{Conclusions}

Water in the cultural landscape is an important topic in the framework of current climate changes. The results of this paper highlighted the active environmental role of natural forests in providing water quality. The paper results fill a knowledge-gap in the scientific literature related to forest ecosystem services based on the Energy-WaterVegetation methodology, which has been emerging in the literature as a new methodological concept for ecosystem service assessment. As the results of this study indicated, in the scale of the river basin, the vegetation of the cultural landscape is able to utilize only about sixty percent of its solar energy potential. In only $1.5 \%$ of the territory of the Czech Republic, society annually loses the supporting ecosystem services at a level higher than 
$25 \%$ of the annual national GDP. Water retention in the landscape needs to be re-evaluated and addressed in accordance with the thermodynamic principles of life and ecosystem functioning in the biosphere. The authors of this study believe that this concept of solar energy transformation in vegetation will be a focus of international environmental research on ecosystem services and climate changes in the near future.

Author Contributions: Conceptualization, J.S., I.M., J.P. and K.S.; methodology, J.S. and J.P.; software, J.E.; validation, K.S. and J.E.; investigation, J.S., I.M., J.P. and K.S.; resources, J.E.; writing-original draft preparation, J.S.; writing —review and editing, J.S. and I.M.; visualization, J.E.; project administration, I.M.; language corrections, K.S. All authors have read and agreed to the published version of the manuscript.

Funding: This research was supported by the grant "Significant Trees-Living Symbols of National and Cultural Identity", No. DG18P020VV027, funded by the Ministry of Culture of the Czech Republic from NAKI II (Programme to Support Applied Research and Experimental Development of National and Cultural Identity). This research was also partly funded by the Technology Agency of the Czech Republic, grant number TD03000093 and by The Ministry of Education, Youth and Sports, grant number RVO MSMT 5096/2019-3.

Institutional Review Board Statement: Not applicable.

Informed Consent Statement: Not applicable.

Data Availability Statement: Not applicable.

Acknowledgments: Authors are grateful to Academic Editor and Reviewers for valuable comments to the manuscript.

Conflicts of Interest: The authors declare no conflict of interest.

\section{Appendix A}

Table A1. Twenty two biotope groups in the Czech Republic according to their provision of four ecosystem services (climatizing services, short water cycle, $\mathrm{O}_{2}$, habitat provision).

\begin{tabular}{|c|c|c|c|c|c|c|c|c|c|c|c|c|c|c|}
\hline \multirow[t]{2}{*}{ No. } & \multirow[t]{2}{*}{ Biotope Groups } & \multirow{2}{*}{$\begin{array}{l}\text { Area } \\
\mathrm{km}^{2}\end{array}$} & \multicolumn{2}{|c|}{ ET } & \multicolumn{2}{|c|}{ SWC } & \multirow{2}{*}{$\frac{\mathrm{O}_{2}}{\mathrm{~kg} / \mathrm{m}^{2} / \mathrm{yr}}$} & \multirow{2}{*}{$\frac{\text { BD }}{\text { points } / \mathrm{m}^{2}}$} & \multirow{2}{*}{$\frac{\text { Clim.s }}{€ / \mathrm{m}^{2} / \mathrm{y}}$} & \multirow{2}{*}{$\frac{\text { SWC }}{€ / \mathrm{m}^{2} / \mathrm{y}}$} & \multirow{2}{*}{$\frac{\mathrm{O}_{2}}{€ / \mathrm{m}^{2} / \mathrm{y}}$} & \multirow{2}{*}{$\frac{\text { BD }}{€ / \mathrm{m}^{2} / \mathrm{yr}}$} & \multirow{2}{*}{$\frac{4 \mathrm{ES}}{\mathrm{E} / \mathrm{m}^{2} / \mathrm{y}}$} & \multirow{2}{*}{$\frac{\sum 4 \mathrm{ES}}{\text { bln. } € / y}$} \\
\hline & & & $\min$ & $\max$ & $\min$ & $\max$ & & & & & & & & \\
\hline 1 & $\begin{array}{c}\text { Water bodies, } \\
\text { courses }\end{array}$ & 675 & 400 & 600 & 200 & 300 & 1.78 & 19 & 56 & 29 & 25 & 1.1 & 111 & 75 \\
\hline 2 & Peatbogs & 23 & 300 & 600 & 200 & 400 & 0.21 & $42-66$ & 50 & 34 & 3 & 3.2 & 91 & 2 \\
\hline 3 & Other wetlands & 364 & 500 & 700 & 250 & 400 & 2.17 & $19-59$ & 67 & 37 & 30 & 1.0 & 136 & 49 \\
\hline 4 & $\begin{array}{l}\text { Ext. used mesic } \\
\text { pastures meadows }\end{array}$ & 2601 & 300 & 500 & 150 & 250 & 1.12 & $33-63$ & 45 & 23 & 16 & 2.3 & 86 & 223 \\
\hline 5 & $\begin{array}{l}\text { Intens. used mesic } \\
\text { pastures meadows }\end{array}$ & 5579 & 300 & 400 & 100 & 200 & 1.48 & 13 & 39 & 17 & 21 & 0.8 & 78 & 434 \\
\hline 6 & $\begin{array}{l}\text { Degraded mesic } \\
\text { pastures meadows }\end{array}$ & 4609 & 200 & 400 & 100 & 150 & 0.85 & 13 & 34 & 14 & 12 & 0.8 & 61 & 279 \\
\hline 7 & $\begin{array}{l}\text { Dry closed } \\
\text { grasslands }\end{array}$ & 40 & 200 & 300 & 50 & 100 & 0.75 & $13-84$ & 28 & 9 & 11 & 2.8 & 50 & 2 \\
\hline 8 & $\begin{array}{l}\text { Dry interspaced } \\
\text { grasslands }\end{array}$ & 172 & 100 & 300 & 40 & 150 & 0.43 & $13-84$ & 22 & 11 & 6 & 2.8 & 42 & 7 \\
\hline 9 & Xeric scrub & 426 & 200 & 300 & 40 & 100 & 0.85 & $10-56$ & 28 & 8 & 12 & 1.9 & 50 & 21 \\
\hline 10 & Mesic scrub & 1959 & 300 & 400 & 100 & 200 & 1.13 & 33 & 39 & 17 & 16 & 1.9 & 74 & 145 \\
\hline 11 & $\begin{array}{c}\text { Alluvial } \\
\text { hygrophilous } \\
\text { scub }\end{array}$ & 17 & 400 & 600 & 150 & 300 & 1.24 & $33-56$ & 56 & 26 & 17 & 2.6 & 102 & 2 \\
\hline 12 & Dry pine forests & 298 & 200 & 400 & 100 & 200 & 0.96 & $40-61$ & 34 & 17 & 13 & 2.9 & 67 & 20 \\
\hline 13 & $\begin{array}{l}\text { Other conifer } \\
\text { forests }\end{array}$ & 6050 & 400 & 600 & 150 & 300 & 1.66 & $36-43$ & 56 & 26 & 23 & 2.4 & 107 & 649 \\
\hline 14 & $\begin{array}{c}\text { Damaged conifer } \\
\text { forests }\end{array}$ & 8222 & 300 & 500 & 100 & 250 & 1.33 & $19-20$ & 45 & 20 & 19 & 1.1 & 85 & 695 \\
\hline 15 & Leafy forests & 6636 & 300 & 600 & 150 & 300 & 1.91 & $38-72$ & 50 & 26 & 27 & 3.2 & 106 & 703 \\
\hline 16 & $\begin{array}{l}\text { Leafy forests } \\
\text { degraded }\end{array}$ & 1632 & 300 & 500 & 100 & 200 & 1.37 & $19-25$ & 45 & 17 & 19 & 1.3 & 82 & 134 \\
\hline
\end{tabular}


Table A1. Cont.

\begin{tabular}{|c|c|c|c|c|c|c|c|c|c|c|c|c|c|c|}
\hline \multirow[t]{2}{*}{ No. } & \multirow[t]{2}{*}{ Biotope Groups } & \multirow{2}{*}{$\begin{array}{l}\text { Area } \\
\mathrm{km}^{2}\end{array}$} & \multicolumn{2}{|c|}{ ET } & \multicolumn{2}{|c|}{ SWC } & \multirow{2}{*}{$\begin{array}{c}\mathrm{O}_{2} \\
\mathrm{~kg} / \mathrm{m}^{2} / \mathrm{yr}\end{array}$} & \multirow{2}{*}{$\begin{array}{c}\text { BD } \\
\text { points } / \mathrm{m}^{2}\end{array}$} & \multirow{2}{*}{$\begin{array}{l}\text { Clim.s } \\
€ / \mathrm{m}^{2} / \mathrm{y}\end{array}$} & \multirow{2}{*}{$\begin{array}{c}\text { SWC } \\
€ / \mathrm{m}^{2} / \mathrm{y}\end{array}$} & \multirow{2}{*}{$\begin{array}{c}\mathrm{O}_{2} \\
€ / \mathrm{m}^{2} / \mathrm{y}\end{array}$} & \multirow{2}{*}{$\begin{array}{c}\mathrm{BD} \\
€ / \mathrm{m}^{2} / \mathrm{yr}\end{array}$} & \multirow{2}{*}{$\begin{array}{c}\mathrm{ESS} \\
\mathrm{\epsilon} / \mathrm{m}^{2} / \mathrm{y}\end{array}$} & \multirow{2}{*}{$\begin{array}{r}\sum 4 \mathrm{ES} \\
\text { bln. } € / \mathrm{y}\end{array}$} \\
\hline & & & $\min$ & $\max$ & $\min$ & $\max$ & & & & & & & & \\
\hline 17 & $\begin{array}{l}\text { Alluvial flooded } \\
\text { forests }\end{array}$ & 924 & 600 & 700 & 200 & 400 & 2.17 & $55-65$ & 73 & 34 & 30 & 3.5 & 141 & 130 \\
\hline 18 & $\begin{array}{l}\text { Solitary trees, } \\
\text { alleys }\end{array}$ & 1276 & 300 & 500 & 100 & 250 & 1.52 & 25 & 45 & 20 & 21 & 1.4 & 87 & 112 \\
\hline 19 & $\begin{array}{l}\text { Arableland:cereal, } \\
\text { root-crops }\end{array}$ & 27605 & 200 & 300 & 50 & 100 & 0.96 & 10 & 28 & 9 & 13 & 0.6 & 51 & 1397 \\
\hline 20 & $\begin{array}{l}\text { Arable land: } \\
\text { fodder, durable } \\
\text { stands }\end{array}$ & 141 & 200 & 400 & 50 & 200 & 2.11 & 10 & 34 & 14 & 30 & 0.6 & 78 & 11 \\
\hline 21 & $\begin{array}{c}\text { Areas without } \\
\text { vegetation }\end{array}$ & 2938 & 1 & 200 & 0 & 50 & 0 & 0 & 11 & 3 & 0 & 0.0 & 14 & 41 \\
\hline 22 & Rock biotopes & 113 & 100 & 300 & 50 & 150 & 0.21 & $40-56$ & 22 & 11 & 3 & 2.8 & 40 & 4 \\
\hline 23 & $\begin{array}{c}\text { Other (semi) } \\
\text { natural biotopes }\end{array}$ & 3780 & 400 & 600 & 150 & 300 & 1.6 & $26-84$ & 56 & 26 & 22 & 2.4 & 106 & 402 \\
\hline \multirow[t]{2}{*}{24} & $\begin{array}{l}\text { Other anthrop. } \\
\text { influenc. biotopes }\end{array}$ & 2787 & 200 & 400 & 100 & 200 & 1.02 & $0-23$ & 34 & 17 & 14 & 0.7 & 66 & 183 \\
\hline & $\begin{array}{c}\text { Czech Republic } \\
\text { total }\end{array}$ & 78,869 & & & & & & & & & & & & 5721 \\
\hline
\end{tabular}

Clim. s. = climate-regulation service, expressed by litres of evapotranspired and condensed water, double air-conditioning effect (evapotranspiration and cooling effect, condensation and warming effect, both latent heat changes of $1 \mathrm{~L}$ of water $=1.4 \mathrm{kWh}$ ); $\mathrm{L} / \mathrm{m}^{2} /$ year $\times € 0.08$ (electricity cost price); SWC = water retention service of the short water cycle; $\mathrm{L} / \mathrm{m}^{2} /$ year $\times € 0.114$ (cost price of $1 \mathrm{~L}$ of distilled water); $\mathrm{O}_{2}$ production $=\mathrm{O}_{2}\left(\mathrm{~kg} / \mathrm{m}^{2} /\right.$ year) $\times 700$ (kg changed to litres) $\times € 0.02$ (cost price of $1 \mathrm{~L}$ of oxygen); $\mathrm{BD}=$ habitat provision service valued by Biotope Valuation Method. Exchange rate $€=$ CZK 25; 2018 point value $=€ 1$.17; Source: [2], (Doi: 10.3390/su10114251) and figures up-dating. SWC: The short water cycle also includes the retention and recycling of cations and nutrients, thus reducing eutrophication, reducing the nutrient load of the water, which is essential in the case of the Švihov reservoir.

\section{References}

1. Neuhäuslova, Z.; Moravec, J.; Chytry, M.; Lozek, V. (Eds.) Map of Potential Natural Vegetation of the Czech Republic; Nature Conservation Agency of the Czech Republic: Prague, Czech Republic, 1997.

2. Seják, J.; Pokorný, J.; Seeley, K. Achieving Sustainable Valuations of Biotopes and Ecosystem Services. Sustainability 2018, $10,4251$. [CrossRef]

3. Chytrý, M. Vegetation of the Czech Republic: Diversity, ecology, history and dynamics. Preslia 2012, 84, 427-504. Available online: http:/ / www.preslia.cz/P123Chytry_HighRes.pdf (accessed on 9 January 2022).

4. Population on the Territory of the Czech Republic from 5th-6th Century. Available online: https://www.czso.cz/documents/10 180/20548149/4032130102.pdf/30451169-a05d-4dc6-853a-09ed;a8ecd685?version=1.0 (accessed on 9 January 2022).

5. Jankovská, V.; Pokorný, J. Palaeoecology of a Medieval Fishpond System (Vajgar, Czech Republic). Folia Geobot. 2002, 37, 253-273. [CrossRef]

6. Odum, E. The Strategy of Ecosystem Development. New Sci. 1969, 164, 3877. [CrossRef]

7. Schneider, E.D.; Sagan, D. Into the Cool, Energy Flow, Thermodynamics, and Life; The University of Chicago Press: Chicago, IL, USA, $2005 ;$ p. 126.

8. Lovelock, J. The Revenge of Gaia, Why the Earth Is Fighting Back-And How We Can Still Save Humanity; Penguin Books: London, UK, 2007; p. 208.

9. Kilianova, H.; Pechanec, V.; Lacina, J.; Halas, P. Ekotony v Soucasne Krajine: Analyza a Modelovani Ekotonu v Povodi Trkmanky; Palacky University: Olomouc, Czech Republic, 2009; pp. 1-167, ISBN 978-80-244-2473-6.

10. Zerbe, S. Potential Natural Vegetation: Validity and Applicability in Landscape Planning and Nature Conservation. Appl. Veg. Sci. 1998, 1, 165-172. [CrossRef]

11. Hengl, T.; Walsh, M.G.; Sanderman, J.; Wheeler, I.; Harrison, S.P.; Prentice, I.C. Global mapping of potential natural vegetation: An assessment of machine learning algorithms for estimating land potential. PeerJ 2018, 6, e5457. [CrossRef]

12. Liska, M.; Soukupova, K.; Dobias, J.; Metelkova, A.; Goldbaach, J.; Kvitek, T. Water Quality in Drinking Water Reservoir Švihov on Želivka River and Its River Basin, with Focus on Specific Organic Coumpounds (in Czech), Vodohospodarske TechnickoEkonomicke Informace, No. 3. 2016. Available online: https://www.vtei.cz/wp-content/uploads/2015/08/5542-VTEI-cislo-316.pdf (accessed on 9 January 2022).

13. Costanza, R.; d’Arge, R.; de Groot, R.; Farber, S.; Grasso, M.; Hannon, B.; Limburg, K.; Naeem, S.; O’Neill, R.V.; Paruelo, J.; et al. The value of the world's ecosystem services and natural capital. Nature 1997, 387, 253-260. [CrossRef]

14. Costanza, R.; de Groot, R.; Sutton, P.; van der Ploeg, S.; Anderson, S.J.; Kubiszewski, I.; Farber, S.; Turner, R.K. Changes in the global value of ecosystem services. Glob. Environ. Change 2014, 26, 152-158. [CrossRef]

15. Costanza, R. Valuing natural capital and ecosystem services toward the goals of efficiency, fairness, and sustainability. Ecosyst. Serv. 2020, 43, 1-7. [CrossRef] 
16. Marshall, A. Principles of Economics; Prometheus Books: London, UK, 1997; p. 253, ISBN 15739-21408.

17. Ripl, W. Management of Water Cycle and energy flow for ecosystem control: The energy-transport-reaction (ETR) model. Ecol. Model. 1995, 78, 61-76. [CrossRef]

18. Ripl, W. Water: The bloodstream of the biosphere. Phil. Trans. R. Soc. Lond. B 2003, 358, 1921-1934. [CrossRef] [PubMed]

19. Reichholf, J. Les, Ekologie Středoevropských Lesů (Forest, Ecology of Central European Forests); Ikar: Praha, Czech Republic, $1999 ;$ p. 223.

20. Brus, J.; Pechnec, V.; Machar, I. Depiction of uncertainty in the visually interpreted land cover data. Ecol. Inform. 2018, 47, 10-13. [CrossRef]

21. Seják, J.; Cudlín, P.; Pokorný, J.; Zapletal, M.; Petricek, V.; Guth, J.; Chuman, T.; Romportl, D.; Skorepova, I.; Vacek, V.; et al. Valuing Ecosystem Functions and Services in the Czech Republic. FoE UJEP, Usti nad Labem 2011. Available online: http:/ / fzp.ujep.cz/projekty/valuingecosystemservices.pdf (accessed on 10 October 2021).

22. Kvítek, T. Retence a Jakost Vody v Povodí Vodárenské Nádrže Švihov na Želivce; Povodí Vltavy: Praha, Czech Republic, 2017; p. 272, ISBN 978-80-270-2488-9.

23. Kenny, A. Ecosystem Services in the New York City Watershed. Available online: https://www.ecosystemmarketplace.com/ articles / ecosystem-services-in-the-new-york-city-watershed-1969-12-31-2 (accessed on 24 October 2021).

24. Miyawaki, A. Restoration of living environment based on vegetation ecology: Theory and practice: Restoration of living environment. Ecol. Res. 2004, 19, 83-90. [CrossRef]

25. Piaggio, M.; Siikamäki, J. The value of forest water purification ecosystem services in Costa Rica. Sci. Total Environ. 2021, 789, 147952. [CrossRef] [PubMed]

26. Bala, G.; Caldeira, K.; Wickett, M.; Phillips, T.J.; Lobell, D.; Delire, C.; Mirin, A. Combined climate and carbon-cycle effects of large-scale deforestation. Proc. Natl. Acad. Sci. USA 2007, 104, 6550-6555. [CrossRef] [PubMed]

27. Daly, H. Some overlaps between the first and second thirty years of ecological economics. Ecol. Econ. 2019, 164, 106372. [CrossRef]

28. Bowen, I.S. The Ratio of Heat Losses by Conduction and by Evaporation from Any Water Surface. Phys. Rev. 1926, 27, 779-787. [CrossRef]

29. Arnold, J.G.; Srinivasan, R.; Muttiah, R.S.; Williams, J.R. Large-area hydrologic modeling and assessment: Part I. Model development. J. Am. Water Resour. Assoc. 1998, 34, 73-89. [CrossRef]

30. Neitsch, S.L.; Arnold, J.G.; Kiniry, J.R.; Srinivasan, R.; Williams, J.R. Soil and Water Assessment Tool Input/Output File Documentation; USDA-ARS Grassland Soil and Water Research Laboratory: Minneapolis, MN, USA, 2004; p. 66.

31. Neitsch, S.L.; Arnold, J.G.; Kiniry, J.R.; Williams, J.R. Soil and Water Assessment Tool Theoretical Documentation. Ver. 2005; USDA-ARS Grassland Soil and Water Research Laboratory, and Texas A\&M University, Blackland Research and Extension Center: Houston, TX, USA, 2005.

32. Van Griensven, A.; Ndomba, P.; Yalew, S.; Kilonzo, F. Critical review of SWAT applications in the upper Nile basin countries. Hydrol. Earth Syst. Sci. 2012, 16, 3371-3381. [CrossRef]

33. Machar, I.; Vozenilek, V.; Simon, J.; Pechanec, V.; Brus, J.; Fulnecek, P.; Vitek, T. Joining of the historical research and future prediction as a support tool for the assessment of management strategy for European beech-dominated forests in protected areas. Nat. Conserv. Bulg. 2017, 22, 51-78. [CrossRef]

34. Buček, A.; Maděra, P.; Úradníček, L. Czech approach to implementation of ecological network. J. Landsc. Ecol. 2012, 5, 14-28. [CrossRef]

35. Zulian, G.; Stange, E.; Woods, H.; Carvalho, L.; Dick, J.; Andrews, C.; Baró, F.; Vizcaino, P.; Barton, D.N.; Nowel, M.; et al. Practical application of spatial ecosystem service models to aid decision support. Ecosyst. Serv. 2018, 29, 465-480. [CrossRef] [PubMed]

36. Decision, No.1386/2013/EU of the European Parliament and of the Council on a General Union Environment Action Programme to 2020 'Living Well, within the Limits of Our Planet'. Available online: http:/ / extwprlegs1.fao.org/docs/pdf/eur129696.pdf (accessed on 9 January 2022).

37. Kubalikova, L.; Kirchner, K.; Kuda, F.; Machar, I. The Role of Anthropogenic Landforms in Sustainable Landscape Management. Sustainability 2019, 11, 4331. [CrossRef] 